\title{
DOK1 wt Allele
}

National Cancer Institute

\section{Source}

National Cancer Institute. DOK1 wt Allele. NCI Thesaurus. Code C52515.

Human DOK 1 wild-type allele is located in the vicinity of $2 \mathrm{p} 13$ and is approximately $3 \mathrm{~kb}$ in length. This allele, which encodes docking protein 1, may be involved in insulin signaling cascade modulation. 